Revue d'histoire de l'Amérique française

REYUE D.HISTOIRE DE L'AMÉRIQUE FRANÇAISE

\title{
Société historique de la Côte-du-Sud
}

\section{Raymond Boucher}

Volume 19, numéro 3, décembre 1965

URI : https://id.erudit.org/iderudit/302507ar

DOI : https://doi.org/10.7202/302507ar

Aller au sommaire du numéro

Éditeur(s)

Institut d'histoire de l'Amérique française

ISSN

0035-2357 (imprimé)

1492-1383 (numérique)

Découvrir la revue

Citer ce document

Boucher, R. (1965). Société historique de la Côte-du-Sud. Revue d'histoire de l'Amérique française, 19(3), 499-499. https://doi.org/10.7202/302507ar d'utilisation que vous pouvez consulter en ligne.

https://apropos.erudit.org/fr/usagers/politique-dutilisation/ 


\section{SOCIÉTÉ HISTORIQUE DE LA COOTE-DU-SUD}

1 - La société a tenu une réunion spéciale dans la Maison Chapais, à Saint-Denis de Kamouraska, le 6 octobre 1964. Mademoiselle Julienne Barnard, auteur des Mémoires Chapais, a donné en la circonstance un exposé sur la maison et JeanCharles Chapais, un des Pères de la Confédération. Des pourparlers sont en cours avec le ministère fédéral du Nord Canadien et le ministère des Affaires Culturelles pour assurer la conservation de cette maison historique.

2 - Lors de ses séances régulières, la société a invité à deux reprises l'archiviste du Collège de Sainte-Anne-de-la-Pocatière, M. l'abbé François Gagnon, à faire connaître quelquesunes des richesses que renferment pour l'histoire de la province de Québec les archives de cette institution. Citons en particulier le volumineux fonds Pilote. L'abbé François Pilote fut, en effet, vers 1850, un chef de premier plan dans l'œuvre nationale de colonisation et de l'enseignement agricole.

3 - La société espère obtenir un subside du ministère des Affaires Culturelles pour procéder à l'inventaire du fonds de l'Ecole d'Agriculture de La Pocatière et pour entreprendre une recherche sur la mentalité rurale au siècle dernier par l'étude de cette documentation et de la Gazette des campagnes publiée de 1861 à 1895 .

4 - Grâce à une aide substantielle du ministère des Affaires Culturelles, notre société fera paraître sous peu son deuxième cahier d'histoire sur les Débuts de Saint-Damase, ouvrage de M. l'abbé Adrien Caron.*

5 - Notre société collabore actuellement à un projet de reconstitution d'un village historique à Saint-Jean-Port-Joli sur le domaine de Philippe-Aubert de Gaspé.

6 - Notre société est membre actif du Conseil d'Aménagement de la Côte-du-Sud.

Le 26 avril 1965.

RAYMOND BOUCHER, ptre,

Secrétaire. no 2.

*Cette brochure de 86 pages vient de paraître: Cahiers d'Histoire, 